\title{
Analisis Video Comments to Video Views Ratio Instagram pada 7 Tim Esports Tersukses di Indonesia
}

\author{
I Gede Wahyu Galang Fajar
}

Gedewahyu459@gmail.com

\begin{abstract}
Instagram can be interpreted as an application that can function as a medium for sharing photos and videos in a social network, allowing users to take photos and videos, and adding filters to add an interesting impression to photos. The total number of Instagram users in Indonesia reached 59,840,000. Just like other social media networks, Instagram has the concept of interaction between users by following or following. Users can also add comments to photos and videos, like, send, and save them in an account. Therefore, there are 7 Esports Teams that use Instagram as a promotional medium, namely: Onic Esport, PG. Barracx Esport, Aerowolf Esport, Bigetron Esport, Boom ID Esport, RRQ Esport, and Evos Esport. The purpose of this study is to calculate the credibility of the Instagram account performance of the 7 Most Successful Esports Teams in Indonesia. The method used for this research is quantitative exploratory method. The results of this study indicate that the Aerowolf Esport Indonesia Team vendor is ranked first and has good account performance credibility.credibility.
\end{abstract}

\begin{abstract}
ABSTRAK
Instagram dapat diartikan sebagai aplikasi yang dapat difungsikan sebagai media berbagi foto dan video dalam sebuah jejaring sosial, memungkinkan pengguna untuk mengambil foto dan video, dan menambahkan filter untuk menambah kesan menarik pada foto. total pengguna Instagram di Indonesia mencapai angka 59.840.000. Sama seperti jejaring media sosial lainnya, Instagram memiliki konsep interaksi antar pengguna dengan mengikuti (following) atau pengikut (follower). Pengguna juga dapat menambahkan komentar pada foto maupun video, menyukai, mengirim, hingga menyimpannya dalam sebuah akun. Karena itu, Adapun 7 Tim Esport yang menjadikan Instagram sebagai media promosi, yaitu : Onic Esport, PG. Barracx Esport, Aerowolf Esport, Bigetron Esport, Boom ID Esport, RRQ Esport, dan Evos Esport. Tujuan dari penelitian ini yaitu untuk menghitung kredibilitas dari performa akun Instagram 7 Tim Esport Tersukses di Indonesia. Metode yang digunakan untuk penelitian ini yaitu metode eksploratif kuantitatif. Hasil dari penelitian ini menunjukan bahwa vendor Tim Aerowolf Esport Indonesia mendapatkan peringkat pertama dan memiliki kredibilitas performa akun yang baik.
\end{abstract}

Keyword : Credibility Account Instagram ; Social Media Marketing ; Social Media Instagram Video Comments to Video Views Ratio ; 7 Tim Esport Tersukses di Indonesia 


\section{PENDAHULUAN}

Teknologi informasi dan komunikasi saat ini telah berkembang dengan pesat, hal ini membuat semakin banyak jenis aplikasi sosial media yang muncul dengan fitur dan fungsi yang berbedabeda. Salah satu aplikasi sosial media yang sering digunakan dan memiliki pengaruh besar terhadap seluruh kefiatan yang ada di dunia adalah Instagram. Penelitian ini dilakukan dengan tujuan untuk menemukan rasio-rasio yang terdapat pada Akun Instagram. Rasio-rasio ini yang nantinya akan digunakan untuk mengukur performa sebuah akun secara matematis.

Media sosial merupakan salah satu dari perkembangan internet. Memiliki kamera berkualitas tinggi pada smartphone membuat banyak orang mempunyai aktivitas baru yang menyenangkan, orang akan mudahnya mengambil gambar dimanapun dan kapanpun, setelah itu diupload ke media sosial. Jenis media sosial yang biasa digunakan antara lainfacebook, twitter, path dan instagram. Instagram merupakan aplikasi berbagi foto yang memungkinkan pengguna mengambil foto, menerapkan filter digital, dan membagikannya ke berbagai layanan jejaring sosial.(Remaja, 2017)

pada penelitian ini saya menggunakan "7 Tim Esports Tersukses di Indonesia" dan mendapatkan berita dari link : https://gamebrott.com/7-tim-esports-tersukses-di-indonesia tersebut saya masukan ke Mendeley lalu mencantumkan referencenya pada word. Penelitian ini dilakukan dengan menggunakan metode ekploratif untuk menemukan variabel-variabel yang terdapat pada Akun Instagram. Variabel tersebut yang nantinya akan dibandingkan dan disandingkan untuk diuji relevansinya sehingga menjadi rasio yang relevan. Rasio yang relevan akan digunakan untuk menilai performa setiap akun yang ada pada sosial media Instagram. Hasil dari penelitian sosial media Instagram ini menunjukan bahwa terdapat 7 variabel, variabel tersebut diantaranya yaitu post, following, video likes, video comments, video views, image comments, image likes. Ketujuh variabel tersebut yang nantinya akan dibandingkan dan disandingkan sehingga menemukan 10 rasio yang relevan. Manfaat yang dapat diambil dari penelitian ini yaitu kedepannya dapat menilai, mengukur serta membandingkan kredebilitas dari setiap Akun Instagram dengan mudah menggunakan 10 rasio yang telah ditemukan.

Instagram adalah sebuah media social untuk sharing berbagi foto dan video yang populer dimana para pengguna dapat mengeskpresikan diri, menonton, dan berbagi video atau foto secara gratis. Saat ini Instagram menjadi media social yang paling dominan Indonesia bahkan 
dunia. Akun di Instagram semakin banyak dan menarik seperti tim e-sport yang kini sudah banyak dan sudah mulai aktif di Instagram sejak 3 tahun lalu. Dari Akun tersebut terdapat "7 Tim Esport Tersukses di Indonesia” antara lain Onic Esport, PG Barracx, Aerowolf, Bigetron Esport, Boom ID, Team RRQ, Evos Esport. (Istianto, 2019)

\section{TINJAUAN PUSTAKA}

Perkembangan bidang teknologi saat ini terjadi begitu pesat. Melalui perkembangan yang terjadi dari waktu ke waktu menimbulkan maraknya aplikasi - aplikasi serta platform media sosial yang bermunculan. Aplikasi yang sangat diminati oleh masyarakat saat ini diantaranya adalah TikTok, Instagram, Twitter, WhatsApp dan yang lain sebagainya. Seiring berjalannya waktu, aplikasi sosial media tersebut dapat menjadi candu bagi kalangan masyarakat. Tidak hanya kalangan remaja yang menggunakan aplikasi sosial media, orang tua bahkan anak-anak juga aktif menggunakan aplikasi sosial media tersebut.

Generasi millennial sangatlah mahir dalam menggunakan teknologi berbasis internet. Adanya teknologi digital ini membuat kita semua yang terhubung ke sosial media yang lama-kelamaan menjadi candu bagi para remaja di generasi $\mathrm{Z}$ maupun generasi millennial. Kecanduan ini membuat mereka betah berlama-lama membuka sosial media melalui smartphone ataupun tablet. Sosial media yang sering digunakan remaja saat ini antara lain adalah Instagram, Facebook, Twitter, Line, dan lain-lain.

Pesatnya perkembangan media sosial kini dikarenakan semua orang seperti bisa memiliki media sendiri. Jika untuk memiliki media tradisional seperti televisi, radio, atau koran dibutuhkan modal yang besar dan tenaga kerja yang banyak, maka lain halnya dengan media. Seorang pengguna media sosial bisa mengakses menggunakan media sosial dengan jaringan internet bahkan yang aksesnya lambat sekalipun, tanpa biaya besar, tanpa alat mahal dan dilakukan sendiri tanpa karyawan. Pengguna media sosial dengan bebas bisa mengedit, menambahkan, memodifikasi baik tulisan, gambar, video, grafis, dan berbagai konten lainnya. Salah satu media sosial yang sangat berkembang pesat sekarang adalah Instagram. Saking populernya Instagram sebagai sebuah media sosial, banyak orang yang tak tahu arti sebenarnya dari pemakaian kata tersebut. Disusun dari dua kata, yaitu "Insta" dan "Gram". Arti dari kata pertama diambil dari istilah "Instan” atau serba cepat/mudah.(Shafita, 2018) 


\section{METODE PENELITIAN}

Penelitian ini menggunakan metode eksploratif kuantitatif untuk mengetahui kredibilitas dari performa akun Instagram 7 Tim Esports Tersukses di Indonesia. Metode eksploratif merupakan penelitian yang memiliki tujuan untuk melakukan eksplorasi atau memperdalam pengetahuan ataupun ide-ide baru mengenai suatu hal yang baru, guna merumuskan permasalahan secara terperinci.

Tujuan dari penelitian ini yaitu mengetahui nilai kredibillitas dari performa akun Instagram 7 Tim Esports Tersukses di Indonesia. Ada beberapa langkah yang harus dilakukan dalam penelitian ini, sehingga mampu menemukan peringkat pertama akun Instagram Tim Esports di Indonesia yang memiliki peringkat terbaik. Langkah-langkah yang dilakukan pada penelitian ini, diantaranya yaitu :

a) Melakukan Eksplorasi Pada Website Untuk Menentukan Objek yang Akan Dianalisa.

Eksplorasi ini dilakukan pada beberapa halaman website yang menyediakan informasi mengenai objek yang akan di teliti. Setelah ekslorasi selesai dilakukan, sehingga ditemukan nama-nama Tim Esports di Indonesia yang akan dijadikan objek analisa. Setelah melakukan eksplorasi pada halaman website, maka langkah selanjutnya yaitu mencari nama akun Instagram dari masing-masing Tim Esport. Pastikan semua Tim memiliki akun pada aplikasi sosial media Instagram.

b) Menghitung Nilai Rata-Rata Variable Dari 7 Tim Esports Tersukses di Indonesia. Pada langkah ini, peneliti menghitung nilai variable video comments dan variable video views. Variabel merupakan sesuatu yang memiliki nilai bervariasi dimana nilai tersebut dapat dijadikan sebagai dasar untuk empat data yang berbeda seperti rasio, skala, ordinal, nominal dan internal. Untuk menghitung nilai rata-rata dari variabel video comments dan variabel video views yaitu dengan cara mengambil minimal 10 postingan kemudian di hitung sehingga menemukan nilai rata-rata dari masing-masing variabel. 


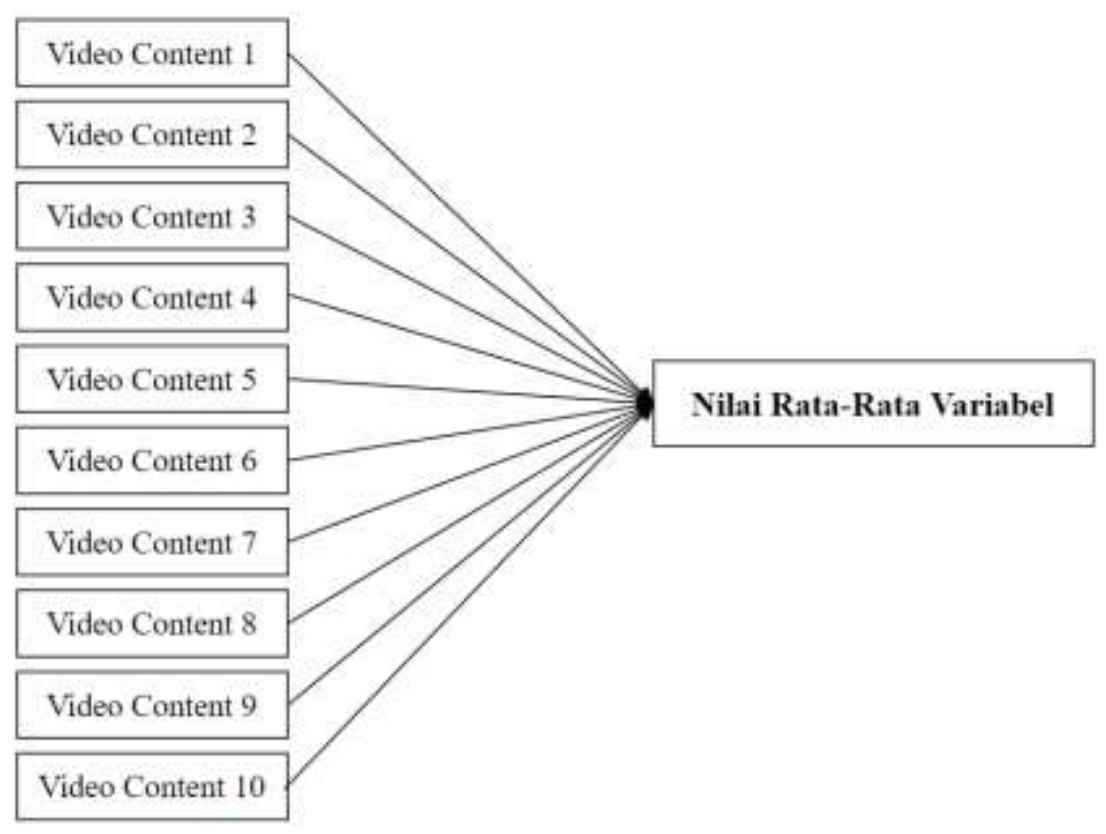

Gambar 1. Analisa Nilai Rata-Rata Variabel.

\section{c) Menghitung Nilai Kredibilitas Rasio}

Untuk menghitung nilai kredibilitas dari video comments to video views ratio, peneliti menggunakan cara membagi nilai variabel pertama dengan nilai variabel kedua. Jika video comments memiliki nilai 100 dan video views memiliki nilai 300, maka cara menghitungnya yaitu $100: 300=0,3$. Dengan begitu nilai dari video comments to video views ratio adalah 0,3 .

\section{d) Menentukan Peringkat Pada Akun Instagram}

Pada langkah terakhir yang dilakukan pada penelitian ini yaitu menentukan peringkat pada masing-masing rasio yang ada. Pada penentuan peringkat perlu melihat karakteristik dari rasio yang di teliti. Jika karakteristik rasio merupakan rendah, maka objek yang memiliki nilai terendah akan mendapatkan angka 7 dan objek yang memiliki nilai tertinggi akan mendapatkan angka 1 . Namun jika rasio memiliki karakteritik tinggi maka objek yang mendapatkan nilai tinggi akan mendapatkan angka 7 dan objek yang mendapatkan nilai terendah akan mendapatkan angka 1. Setelah mendapatkan hasil kredibilitas ratio maka dapat disimpulkan objek yang mana mendapatkan peringkat 1 sampai dengan peringkat 7 . 


\section{HASIL DAN PEMBAHASAN}

Akun instagram pada 7 tim esport tersukses di Indonesia, diantaranya :

\section{ONIC Esports}
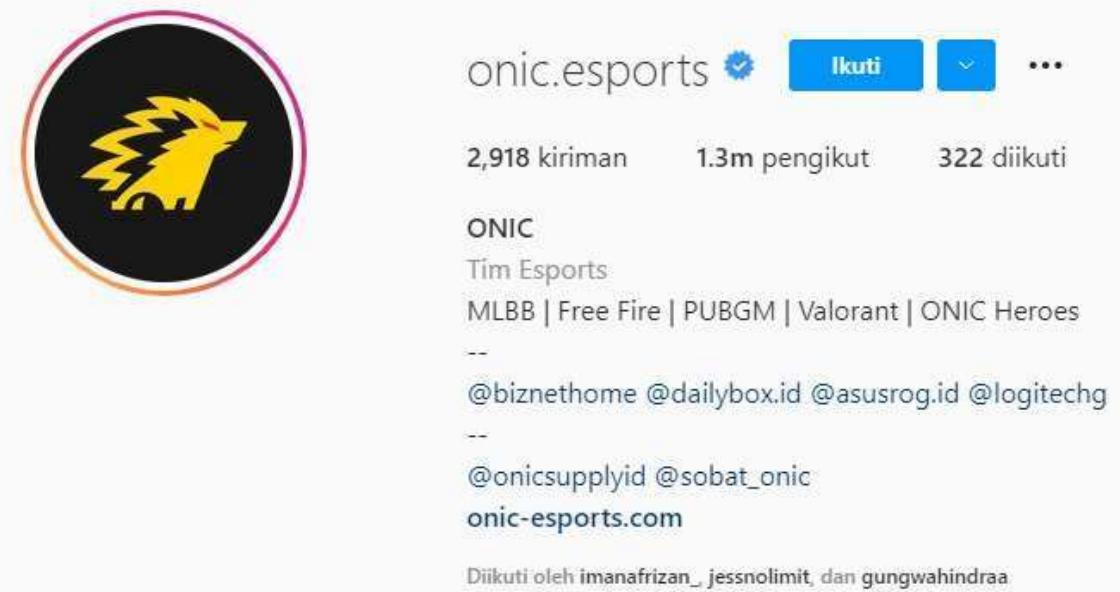

Diikuti oleh imanafrizan_ jessnolimit, dan gungwahindraa

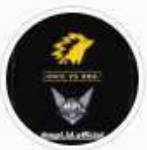

MPL S8

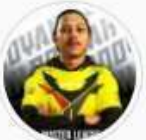

FFML S4

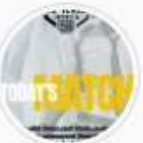

PMPL 54

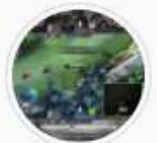

MPL S7

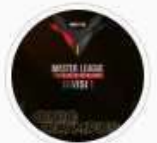

FFML S3

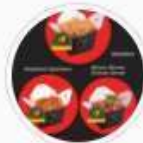

DAILYBOX

Gambar 1. Akun Instagram Onic Esports

Sumber : https://www.instagram.com/onic.esports/ (akses pada 22-10-2021)

\section{PG. Barracx Esports}

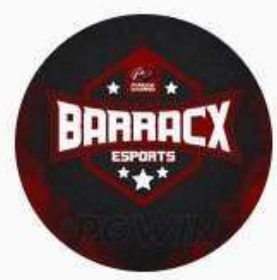

\section{pg.barracx Ikuti $\square \cdots$}

893 kiriman $\quad 53 \mathrm{k}$ pengikut 301 diikuti

PondokGaming BarracX

Tim Esports

Official account team PG.BarracX| Pesan Bomber dan Hoodie 4

\#PGWIN \#TteSPORTS \#ACER \#PredatorWarrior \#DXRacer \#Breakroom \#ringerhut

\#firstmedia

www.tokopedia.com/pgbarracx

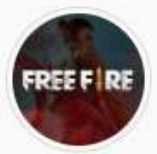

FREE FIRE

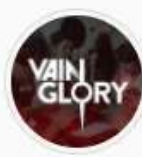

VAINGLORY

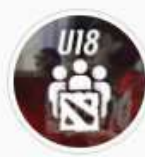

U18 DOTA2

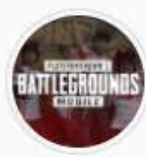

PUBGM

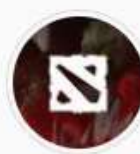

DOTA2

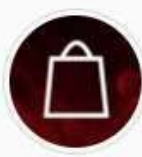

BRX STORE
FIFR19

FIFA19

Gambar 2. Akun Instagram PG. Barracx

Sumber : https://www.instagram.com/pg.barracx/ (akses pada 22-10-2021) 
3. Aerowolf Esports

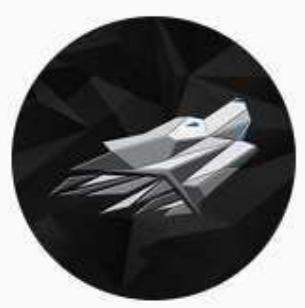

\section{aerowolfproteam $*$ ikut $\backsim \cdots$ \\ 154 kiriman $\quad 404 k$ pengikut 129 diikuti}

AEROWOLF PRO TEAM

Tim Esports

\#RISINGWOLF

Dikuti oleh imanafrizan, jessnolimit, dan kaesangp

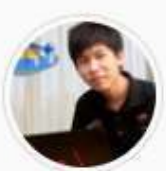

Asus ROG

Gambar 3. Akun Instagram Aerowolf

Sumber : https://www.instagram.com/aerowolfproteam/ (akses pada 22-10-2021)

\section{Bigetron Esports}

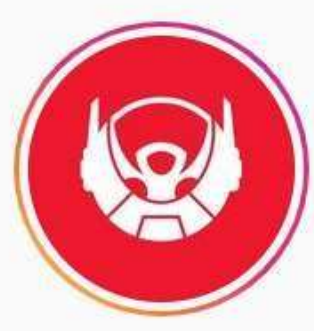

\section{bigetronesports * lkuti $\ldots$}

3,415 kiriman $\quad 1.5 \mathrm{~m}$ pengikut 8 diikuti

Bigetron Esports

Tim Olahraga Profesional

ID Indonesia's Leading Esports Organization

思@belletronesports

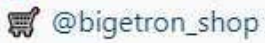

\#BTRWIN

1 LEARN MORE I

linktr.ee/bigetronesports

Diikuti oleh imanafrizan_, arya_wirtiana, priyanaadm +6 lainnya

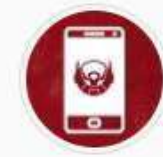

Wallpapers

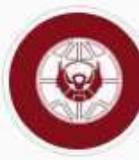

Website

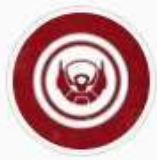

Sponsors

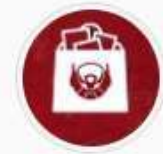

Shop

Gambar 4. Akun Instagram Bigetron Esports

Sumber : https://www.instagram.com/bigetronesports/ (akses pada 22-10-2021) 


\section{Boom ID Esports}

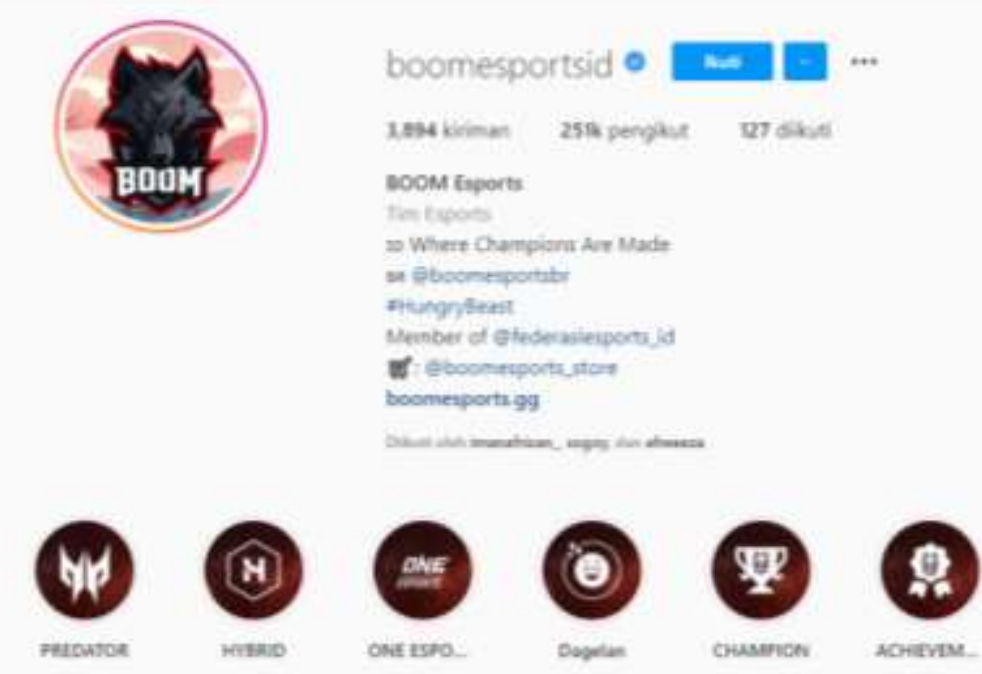

Gambar 5. Akun Instagram Boom ID Esports

Sumber : https://www.instagram.com/boomesportsid/ (akses pada 22-10-2021)

\section{RRQ Esports}
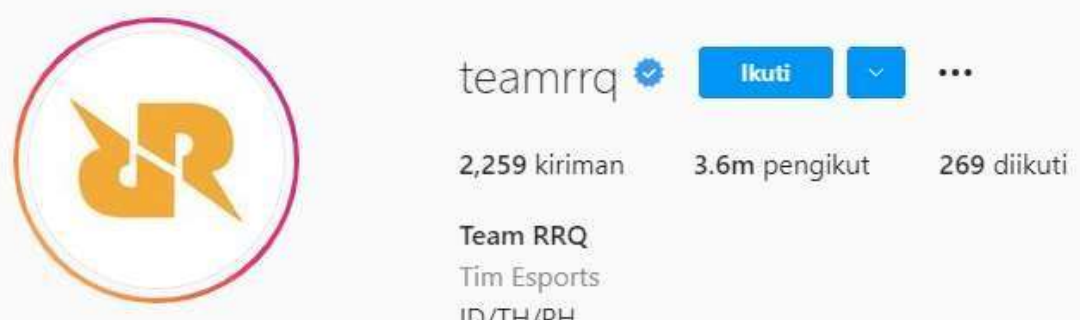

Team RRQ

Tim Esports

$\mathrm{ID} / \mathrm{TH} / \mathrm{PH}$

@rrq_store

@rrq_kingdomm

Partners

@biznethome@asusrog.id @sukro@popmieofficial @cinema.21 @kedaikopikulo Ink.to/vivaRRQ

Diikuti oleh dadylon_ jessnolimit, imanafrizan_, + 2 lainnya

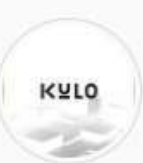

KULO

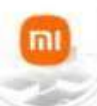

Xiaomi

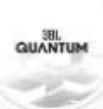

JBL

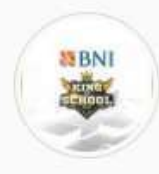

King of Sch...

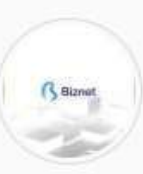

Biznet \#2

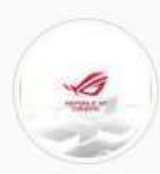

ROG anceg

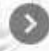

Sukro

Gambar 6. Akun Instagram RRQ Esports

Sumber : https://www.instagram.com/teamrrq/ (akses pada 22-10-2021) 


\section{Evos Esports}

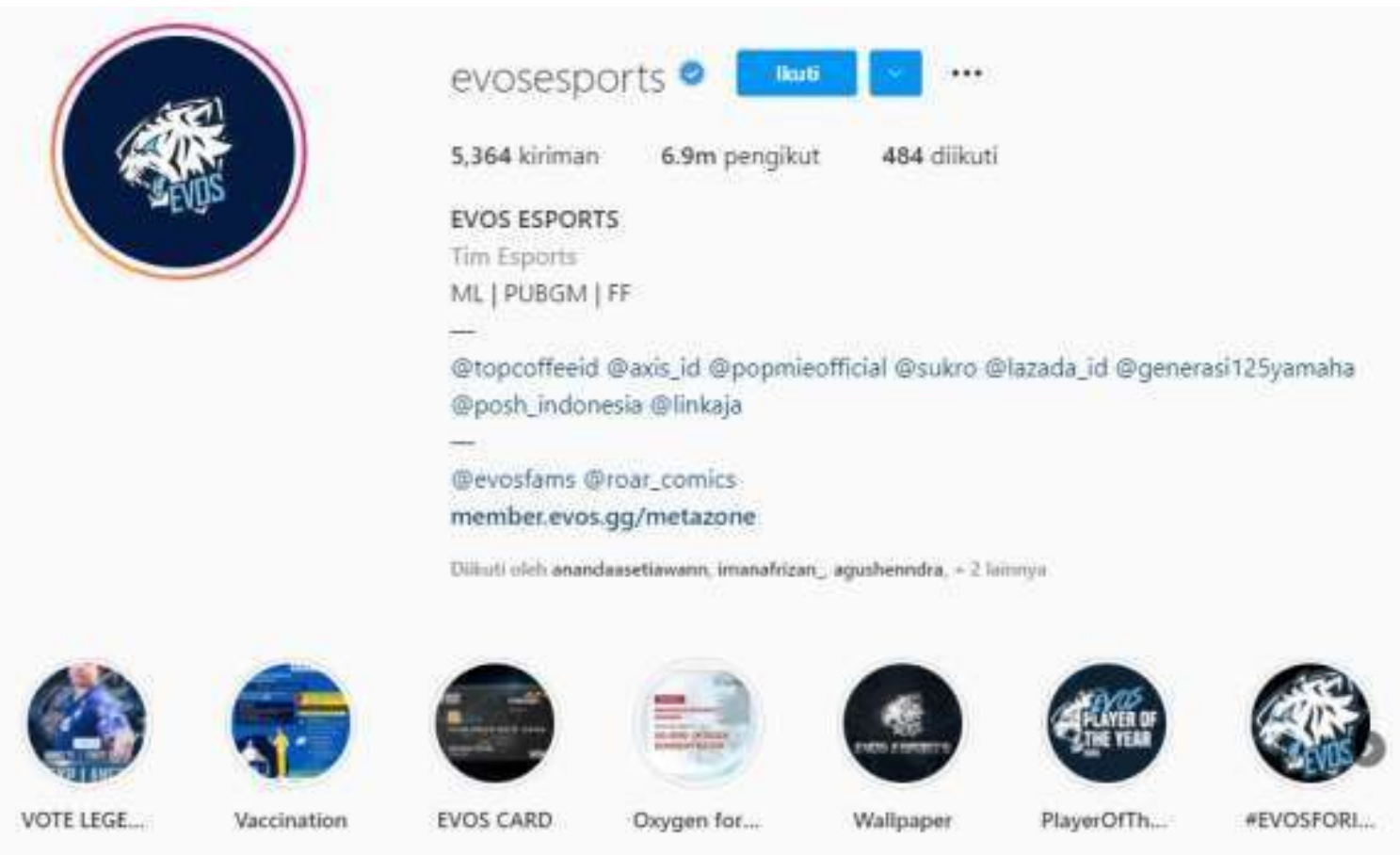

Gambar 7. Akun Instagram Evos Esports

Sumber : https://www.instagram.com/evosesports/ (akses pada 22-10-2021)

Dari ketujuh akun Instagram Tim Esport tersukses di Indonesia, peneliti menemukan nilai dari masing-masing variabel yang ada untuk menghitung rasio Video Comments to Video Views dari setiap akun. Pada akun Instagram terdapat 7 variabel, diantaranya yaitu :

1. Post

2. Following

3. Video Likes

4. Video Comments

5. Video Views

6. Image Comments

7. Image Likes

Dari tujuh variabel tersebut peneliti hanya fokus untuk menemukan hasil dari 2 variabel, yaitu :

1. Video Comments

2. Video Views

Dari kedua variabel tersebut kemudian dianalisa sehingga menemukan nilai rata-rata dari variabel video comments dan variabel video views. Untuk menghitung nilai rata-rata dari variabel video comments dan variabel video views yaitu dengan cara mengambil minimal 10 
postingan kemudian di hitung sehingga menemukan nilai rata-rata dari masing-masing variabel. Berikut merupakan tabel nilai rata-rata dari masing-masing tim esport di Indonesia, yaitu :

Tabel 1. Analisa Nilai Rata-Rata Nilai Variabel Video Comments dan Video Views Akun Instagram ONIC Esports

\begin{tabular}{|c|c|c|}
\hline No. & Comments & Views \\
\hline 1. & 64 & 4.636 \\
\hline 2. & 51 & 3.553 \\
\hline 3. & 23 & 10.300 \\
\hline 4. & 27 & 2.586 \\
\hline 5. & 17 & 12.800 \\
\hline 6. & 21 & 2.915 \\
\hline 7. & 16 & 10.400 \\
\hline 8. & 16 & 8.250 \\
\hline 9. & 45 & 13.300 \\
\hline 10 & 23 & 9.464 \\
\hline Total & 30,3 & 7.820 \\
\hline
\end{tabular}

Sumber : Pengolah Data Excel

Tabel 2. Analisa Nilai Rata-Rata Nilai Variabel Video Comments dan Video Views Akun Instagram PG. Barracx Esports

\begin{tabular}{|c|c|c|}
\hline No. & Comments & Views \\
\hline 1. & 33 & 5.321 \\
\hline 2. & 11 & 5.841 \\
\hline 3. & 0 & 3.075 \\
\hline 4. & 0 & 2.453 \\
\hline 5. & 11 & 6.582 \\
\hline 6. & 3 & 5.605 \\
\hline 7. & 0 & 2.187 \\
\hline 8. & 0 & 2.340 \\
\hline 9. & 0 & 1.646 \\
\hline
\end{tabular}




\begin{tabular}{|c|c|c|}
\hline 10 & 2 & 2.769 \\
\hline Total & 6 & 3.782 \\
\hline
\end{tabular}

Sumber : Pengolah Data Excel

Tabel 3. Analisa Nilai Rata-Rata Nilai Variabel Video Comments dan Video Views Akun Instagram Areowolf Esports

\begin{tabular}{|c|c|c|}
\hline No. & Comments & Views \\
\hline 1. & 4 & 4.216 \\
\hline 2. & 0 & 88.400 \\
\hline 3. & 0 & 96.400 \\
\hline 4. & 230 & 80.600 \\
\hline 5. & 86 & 49.400 \\
\hline 6. & 213 & 199.000 \\
\hline 7. & 113 & 126.000 \\
\hline 8. & 11 & 31.800 \\
\hline 9. & 744 & 8.370 \\
\hline 10 & & 790.186 \\
\hline Total & & \\
\hline
\end{tabular}

Sumber : Pengolah Data Excel

Tabel 4. Analisa Nilai Rata-Rata Nilai Variabel Video Comments dan Video Views Akun Instagram Bigeron Esports

\begin{tabular}{|c|c|c|}
\hline No. & Comments & Views \\
\hline 1. & 45 & 33.000 \\
\hline 2. & 412 & 164.000 \\
\hline 3. & 89 & 94.800 \\
\hline 4. & 1395 & 415.000 \\
\hline 5. & 48 & 63.900 \\
\hline 6. & 538 & 176.000 \\
\hline 7. & 750 & 204.000 \\
\hline 8. & 228 & 164.000 \\
\hline 9. & & 208.000 \\
\hline
\end{tabular}




\begin{tabular}{|c|c|c|}
\hline 10 & 21 & 48.000 \\
\hline Total & 383,7 & 157.070 \\
\hline
\end{tabular}

Sumber : Pengolah Data Excel

Tabel 5. Analisa Rata-Rata Nilai Variabel Video Comments dan Video Views Akun Instagram Boom ID Esports

\begin{tabular}{|c|c|c|}
\hline No. & Comments & Views \\
\hline 1. & 48 & 21.800 \\
\hline 2. & 28 & 21.300 \\
\hline 3. & 17 & 10.700 \\
\hline 4. & 47 & 11.600 \\
\hline 5. & 26 & 7.257 \\
\hline 6. & 50 & 17.300 \\
\hline 7. & 7 & 5.044 \\
\hline 8. & 17 & 5.940 \\
\hline 9. & 47 & 11.800 \\
\hline 10 & 68 & 12.300 \\
\hline Total & 35,5 & 12.504 \\
\hline
\end{tabular}

Sumber : Pengolah Data Excel

Tabel 6. Analisa Rata-Rata Nilai Variabel Video Comments dan Video Views Akun Instagram RRQ Esports

\begin{tabular}{|c|c|c|}
\hline No. & Comments & Views \\
\hline 1. & 1264 & 320.000 \\
\hline 2. & 475 & 156.000 \\
\hline 3. & 917 & 337.000 \\
\hline 4. & 574 & 250.000 \\
\hline 5. & 233 & 187.000 \\
\hline 6. & 216 & 66.900 \\
\hline 7. & 97 & 71.800 \\
\hline 8. & 1.284 & 198.000 \\
\hline 9. & 654 & 257.000 \\
\hline
\end{tabular}




\begin{tabular}{|c|c|c|}
\hline 10 & 92 & 83.500 \\
\hline Total & 580,6 & 192.720 \\
\hline
\end{tabular}

Sumber : Pengolah Data Excel

Tabel 7. Analisa Rata-Rata Nilai Variabel Video Comments dan Video Views Akun Instagram Evos Esports

\begin{tabular}{|c|c|c|}
\hline No. & Comments & Views \\
\hline 1. & 30 & 36.100 \\
\hline 2. & 288 & 92.700 \\
\hline 3. & 140 & 108.000 \\
\hline 4. & 47 & 68.000 \\
\hline 5. & 42 & 73.900 \\
\hline 6. & 193 & 4.515 \\
\hline 7. & 100 & 63.100 \\
\hline 8. & 72 & 159.000 \\
\hline 9. & 341 & 304.000 \\
\hline 10 & 125,7 & 111.332 \\
\hline Total & & \\
\hline & Sum & \\
\hline
\end{tabular}

Sumber : Pengolah Data Excel

Setelah menghitung nilai rata-rata tersebut, maka akan menemukan hasil akhir nilai rata-rata dari variabel video comments dan Video Views. Berikut tabel nya :

Tabel 8. Nilai Variabel Pada Akun Instagram 7 Tim Esports Tersukses di Indonesia

\begin{tabular}{|c|c|c|c|c|c|c|c|}
\hline \multicolumn{8}{|c|}{ Tabel Nilai Masing-Masing Variable } \\
\hline Variable & onic.esport & pg.barracx & aerowolfproteam & bigetronesport & boomesportsid & teamrrq & evosesports \\
\hline Comments & 30,3 & 6 & 744 & 383,7 & 35,5 & 580,6 & 125,7 \\
\hline Views & 7.820 & 3.782 & 790.186 & 157.070 & 12.504 & 192.720 & 111.332 \\
\hline
\end{tabular}

Sumber : Pengolah Data Excel

Pada akun Instagram terdapat 14 rasio yang relevan digunakan untuk mengukur kredibilitas pada masing-masing akun. Namun pada penelitian kali ini hanya berfokus untuk menghitung Video Comments to Video Views Ratio. Untuk menghitung kredibilitas dari masing-masing akun Instagram setiap Tim Esports, peneliti menghitung dengan cara : 
variabel 1 akan dibagi dengan variabel 2, sehingga ditemukan hasil analisisa dari rasio tersebut.

Tabel 9. Hasil Perhitungan Rasio Akun Instagram 7 Tim Esports Tersukses di Indonesia

\begin{tabular}{|c|c|c|c|c|c|c|c|c|}
\hline \multicolumn{1}{|c|}{ Tabel Ratio } \\
\hline Ratio & onic.esport & pg.barracx & aerowolfproteam & bigetronesport & boomesportsid & teamrrq & evosesports & Karakteristik \\
\hline $\begin{array}{c}\text { Comments to } \\
\text { Views }\end{array}$ & 0,003874482 & 0,001586504 & 0,00094155 & 0,00244286 & 0,002839069 & 0,003012661 & 0,001129061 & Tinggi \\
\hline
\end{tabular}

Sumber : Pengolah Data Excel

Video Comments to Video Views Ratio memiliki karakteristik yang tinggi, artinya semakin tinggi nilai yang dihasilkan maka semakin baik kredibilitas dari performa akun tersebut.

Untuk memberikan peringkat pada masing-masing Vendor Smartphone, peneliti memberikan angka 7 kepada Tim Esports yang mendapatkan nilai tertinggi dan angka 1 untuk vendor smartphone yang mendapatkan nilai terendah. Berikut merupakan tabel urutan nilai yang dihasilkan oleh masing-masing vendor smartphone.

Tabel 10. Nilai Rasio Akun Instagram 7 Tim Esports Tersukses di Indonesia

\begin{tabular}{|c|c|c|c|c|c|c|}
\hline \multicolumn{7}{|c|}{ Tabel Peringkat } \\
\hline onic.esport & pg.barracx & aerowolfproteam & bigetronesport & boomesportsid & teamrrq & evosesports \\
\hline 1 & 5 & 7 & 4 & 3 & 2 & 6 \\
\hline
\end{tabular}

Sumber : Pengolah Data Excel

Dari Tabel Nilai Rasio Akun Instagram 7 Tim Esports Tersukses di Indonesia dapat simpulkan bahwa Aerowolf Esports Indonesia mendapatkan nilai tertinggi untuk rasio Video Comments to Video Views. Sedangkan akun Instagram ONIC Esports mendapatkan nilai terendah untuk rasio ini. Jadi, pada penelitian ini Aerowolf Esports memiliki kredibilitas performa yang lebih baik dibandingkan dengan Tim Esports yang lainnya.

\section{KESIMPULAN}

Tujuan dari penelitian ini adalah mengetahui kredibilitas performa dari Akun Instagram 7 Tim Esports Tersukses di Indonesia menggunakan Video Comments to Video Views Ratio. Akun Instagram 7 Tim Esports Tersukses di Indonesia tersebut diantaranya : ONIC Esports, PG. Barracx Esports, Aerowolf Esports, Bigetron Esports, Boom ID Esports, RRQ Esports, dan Evos Esports. Dari Ketujuh Tim Esports tersebut dapat disimpulkan bahwa : 
1. Peringkat pertama diraih oleh Tim Esport Aerowolf dengan nilai tertinggi yaitu 0,00094155

2. Peringkat kedua diraih oleh Tim Esport Evos dengan nilai 0,00112906

3. Peringkat ketiga diraih oleh Tim Esport PG. Barracx dengan nilai 0,001586504

4. Peringkat keempat diraih oleh Tim Esport Bigetron dengan nilai 0,00244286

5. Peringkat kelima diraih oleh Tim Esport Boom ID dengan nilai 0,002839069

6. Peringkat keenam diraih oleh Tim Esport RRQ dengan nilai 0,003012661

7. Peringkat ketujuh diraih oleh Tim Esport ONIC dengan nilai 0,003874482 


\section{DAFTAR PUSTAKA}

Istianto, R. (2019). 7 Tim Esports Tersukses di Indonesia. 2021. https://gamebrott.com/7-timesports-tersukses-di-indonesia

Remaja, D. I. K. (2017). Motif Penggunaan Media Sosial Instagram. Communication, Universitas Pembangan Nasional “Veteran” Jakarta, 8(April), 51-65.

Shafita, R. (2018). Studi Deskriptif Kuantitatif Pengaruh Media Sosial Instagram dengan Minat Wisatawan Terhadap Pariwisata di Yogyakarta (Studi Kasus di PT. BKS Tour Services Periode Oktober - November 2017). Mercubuana Yogyakarta. 